\title{
PENGAJARAN MENGGUNAKAN METODE KAISA DALAM MENGHAFAL AL QURAN PADA ANAK
}

\author{
Umi Salamah \\ STAI Ma'had Aly Al-Hikam Malang \\ Umisalah393@gmail.com
}

\begin{abstract}
Abstrak
Metode kaisa adalah cara menghafal al-Qur'an yang berorientasi pada hafalan dan pemahaman ayat alQur'an beserta artinya melalui gerakan atau kinestetik yang disesuaikan dengan arti setiap ayat sehingga memberikan kemudahan santri untuk memahami dan mengingat setiap ayat al-Qur'an yang diberikan. Tahapan metode kaisa : Guru memberi salam, menyiapkan atau memberi aba-aba kepada santri persiapan proses belajar mengajar, presensi kehadiran santri, membaca basmalah dan do'a sebelum belajar, Muroja'ah atau mengulang hafalan, tambahan hafalan dengan membaca ayat perkata dengan gerakan/kinestetik, menjelaskan hukum tajwid serta maknanya/tafsirnya, santri melafalkan ayat secara berulang-ulang sampai ayat tersebut dihafal, satu per satu santri melafalkan ayat sesuai hukum tajwidnya dan menerjemahkan per kata, guru menyimak hafalan ayat yang dihafalkan oleh masing-masing santri, guru membenarkan jika ada kesalahan dengan hukum tajwid serta artinya, setelah ayat pertama dihafal, guru membimbing santri untuk lanjut ke ayat berikutnya dengan perlakuan yang sama, merefleksi pembelajaran dengan memberi game sambung ayat (yaitu hafalan surat-surat secara berkesinambungan), penutup pembelajaran dengan do'a senandung al-Qur'an dan do'a kafaratul majelis secara berjama'ah.
\end{abstract}

Kata Kunci; metode kaisa, menghafal al-Qur'an

\section{Pendahuluan}

Al-Qur'an adalah pedoman hidup bagi umat Islam, sehingga mempelajari dan memahaminya merupakan kewajiban bagi umat Islam. Hal 
ini bisa dimulai sejak dini, yaitu masa anak-anak. Agar menumbuhkan rasa ingin tahu dalam mempelajari Al-Qur'an, dibutuhkan rasa cinta atau ketertarikan untuk mempelajarinya. Salah satu wujud cinta terhadap AlQur'an adalah dengan menghafalkan dan memahami maknanya serta menjaga hafalannya.

Tingginya minat orang tua untuk membekali anak tentang agama terutama dalam mengahafal Al-Qur'an membuat banyak instansi pendidikan yang menyambut baik niat ini. Banyak madrasah/sekolah, madrasah diniyah yang menjadikan program hafalan sebagai program unggulan. Banyak metode-metode yang diterapkan agar proses menghafal bisa cepat dan mudah.

Dunia anak adalah dunia bermain, segala aktifitas yang mampu menarik perhatian anak-anak adalah yang menarik dan menyenangkan. Menurut Piaget, anak usia 0-7 tahun berada pada tahap pra-operasional. Pada tahap ini, kemampuan anak untuk berpikir tentang benda, kejadian, atau orang lain mulai berkembang. Anak sudah mulai mengenali simbol (kata-kata, angka, gerk tubuh, atau gambar) untuk mewakili benda-benda di sekitarnya. Namun, pada tahap ini cara berpikir anak masih tergantung pada objek konkret, rentang waktu kekinian, dan tempat di mana ia berada (concrete, here, and now). Anak tahap pra-operasional belum mamppu berpikir abstrak sehingga memerlukan simbol yang konkret saat menanamkan konsep pada mereka.

Metode kaisa sangat sesuai diterapkan dalam pembelajaran menghafal Al-Qur'an pada anak. Metode ini memadukan antara melafalkan dengan benar, gerakan, dan arti. Sehingga dalam satu kegiatan sudah mengkombinasikan beberapa aspek kecerdasan. Dengan gerakan anak menjadi antusias untuk mempelajari dan menghafal Al-Qur'an, setiap gerakan sesuai dengan arti dari ayat yang dibacakan.

\section{Pengajaran Metose KAISA dalam Menghafal al-Quran}

Menurut kamus besar bahasa Indonesia (KBBI) metode adalah cara kerja yang bersistem untuk memudahkan pelaksanaan suatu kegiatan guna mencapai tujuan yang ditentukan. Berdasarkan pengertian tersebut dapat diartikan bahwa metode adalah cara yang digunakan untuk mencapai tujuan. Jadi, metode yang digunakan harus sesuai dengan tujuan yang akan dicapai.

Menghafal Al-Qur'an adalah proses yang tidak mudah dan harus terus berkesinambungan. Mengajarkan menghafal Al-Qur'an dibutuhkan metode yang tepat agar anak mudah menghafal dan tertarik untuk mempelajarinya. Salah satu metode yang sesuai untuk anak dalam menghafal Al-Qur'an adalah metode kaisa. 
Metode Kaisa adalah cara menghafal al-Qur'an yang berorientasi pada hafalan dan pemahaman ayat al-Qur'an beserta artinya melalui gerakan atau kinestetik yang disesuaikan dengan arti tiap ayat sehingga memberikan kemudahan bagi anak untuk memahami dan mengingat setiap ayat al- Qur'an yang diberikan. Metode Kaisa adalah salah satu dari sekian banyak metode dalam menghafal al-Qur'an, namun kekuatan metode Kaisa terletak pada pendekatan agar anak menjadi rileks saat menghafal, dan tetap mengutamakan tajwid.

Metode ini sesuai untuk anak karena rentang konsentrasi anak masih relatif pendek, dengan gerakan anak tidak harus duduk diam mendengarkan tetapi sambil bergerak sesuai dengan arti ayat yang dibacakan. Hal ini juga menambah perbendaharaan kata dan gerak anak. Ada beberapa kecerdasan yang diasah dalam metode kaisa, kecerdasan linguistik, kecerdasan kinestetik, kecerdasan audio visual, dan kecerdasan inter personal. Metode ini sesuai untuk anak kinestetik, yang gaya belajarnya lebih menyukai aktifitas fisik, melatih anak intra personal untuk bersosialisasi, dan membantu anak audio visual untuk lebih mudah menghafal karena belajar dengan mendengar sekaligus melihat.

Berikut langkah-langkah pembelajaran menghafal dengan metode Kaisa:

1. Guru memberi salam

2. Menyiapkan atau memberi aba-aba kepada santri persiapan proses belajar mengajar.

3. Presensi kehadiran santri

4. Membaca basmalah dan do'a sebelum belajar

5. Muroja'ah atau mengulang hafalan

6. Tambahan hafalan dengan membaca ayat perkata dengan gerakan/kinestetik

7. Menjelaskan hukum tajwid serta maknanya/tafsirnya

8. Santri melafalkan ayat secara berulang-ulang sampai ayat tersebut dihafal

9. Satu per satu santri melafalkan ayat sesuai hukum tajwidnya dan menerjemahkan per kata

10. Guru menyimak hafalan ayat yang dihafalkan oleh masing-masing santri

11. Guru membenarkan jika ada kesalahan dengan hukum tajwid serta artinya

12. Setelah ayat pertama dihafal, guru membimbing santri untuk lanjut ke ayat berikutnya dengan perlakuan yang sama

13. Merefleksi pembelajaran dengan memberi game sambung ayat (yaitu hafalan surat-surat secara berkesinambungan) 
14. Menutup pembelajaran dengan do'a senandung al-Qur'an dan do'a kafaratul majelis secara berjama'ah.

Mengkombinasikan otak kanan dan kiri memang tidak mudah, akan tetapi ini menarik untuk anak. Di masa golden age anak, yang daya serapnya sangat baik dan rasa ingin tahu yang tinggi membuat penerapan metode ini efektif. Anak tidak harus duduk manis mendengarkan murotal dan mengulang-ngulang bacaan/dril. Kegiatan pembelajarannya dengan gerakan, bermain, kuis, dan diberi kesempatan satu-satu untuk mempraktikkan. Gerakan sesuai dengan artinya, sehingga anak tahu arti setiap ayat. Misalnya, kata syaithon maka kedua tangan di atas kepala sambil mengacungkan dua jari telunjuknya artinya setan. Kata Arrahman (Maha Pengasih), kedua tangan disilangkan di dada, kata Arrahiim (Maha Penyayang), kedua tangan diletakkan di bawah dagu, seperti menyangga dagu. Ketika anak lupa bacaannya, bisa memanggil memori anak hanya dengan isyarat gerakan.

\section{Kelebihan dan kelemahan metode kaisa}

1. Kelebihan metode kaisa:

a. Menarik untuk anak karena menggunakan gerakan

b. Memperkaya perbendaharaan kata dan gerakan pada anak

c. Mengkombinasikan beberapa kecerdasan

d. Melatih otak kanan dan kiri

e. Anak tidak hanya menghafal tapi juga memahami tajwid dan artinya

2. Kelemahan metode kaisa:

a. Proses menghafal membutuhkan waktu lebih lama

b. Membutuhkan keterampilan khusus guru

c. Membutuhkan perencanaan yang matang

\section{Kesimpulan}

Pembelajaran metode kaisa dalam menghafal Al-Qur'an sangat sesuai diterapkan pada anak. Metode dirancang untuk mempermudah anak dalam menghafal Al-Qur'an dengan mengombinasikan gerakan, pelafalan, tajwid dan tafsir Al-Qur'an. Proses pembelajaran yang menyenangkan, mengoptimalkan otak kanan dan otak. kiri, dan menghubungkan beberapa kecerdasan. Diharapkan metode ini mampu membawa anak-anak mencintai, menghafal, memahami, dan mentadaburi Al-Qur'an dalam kehidupannya.

\section{Daftar Rujukan}

Bersama Islam, Lima bersaudara Ini Hafal Quran dengan Metode Unik, (online), Tersedia: www.bersamaislam.com/2016/04/limabersaudara-ini-hafal-quran dengan.html?m=1, html (28 Juni 2018) 
Pengertian Metode, (online), Tersedia : https://kbbi.kemdikbud.go.id/ entri/metode html (4 Juli 2018)

Teori Tahap Perkembangan Anak Piaget, (online), Tersedia https://satujam.com/teori-tahap-perkembangan-anak-piaget/. Html (10 Juli 2018)

Metode Kaisa, (online), Tersedia: http://digilib.iainkendari.ac.id/786/3/ BAB\%20II.pdf 